medRxiv preprint doi: https://doi.org/10.1101/2020.12.09.20246520; this version posted December 11, 2020. The copyright holder for this preprint (which was not certified by peer review) is the author/funder, who has granted medRxiv a license to display the preprint in perpetuity.

It is made available under a CC-BY-NC-ND 4.0 International license .

1 TITLE

2 Impact of Nasopharyngeal Specimen Quality on SARS-CoV-2 Test Sensitivity

3 ABBREVIATED TITLE

4 Specimen Quality and SARS-CoV-2 Ct

\title{
5 AUTHORS
}

6 Melissa Richard-Greenblatt, PhD (1); Matthew J. Ziegler, MD, MS (2,3); Valerie Bromberg (2);

7 Elizabeth Huang (2); Hatem Abdallah (2); Pam Tolomeo, MS (2); Ebbing Lautenbach, MD,

8 MPH, MS (2,3); Laurel Glaser, MD, PhD (1); Brendan J. Kelly, MD, MS (2,3)

\section{AFFILIATIONS}

101 - Department of Pathology and Laboratory Medicine;

112 - Division of Infectious Diseases, Department of Medicine;

123 - Department of Biostatistics, Epidemiology, and Informatics, Perelman School of Medicine,

13 University of Pennsylvania, Philadelphia, PA

\section{CORRESPONDING AUTHOR CONTACT}

15 Brendan J. Kelly, MD, MS - brendank@pennmedicine.upenn.edu

\section{AUTHORS' CONTRIBUTIONS}

$17 \mathrm{MRG}$ - study design, data collection, manuscript;

18 MJZ - study design, data analysis, manuscript;

19 VB - data collection, manuscript;

20 EH - data collection, manuscript;

21 HA - data collection, manuscript;

22 PT - data collection, manuscript;

23 EL - data analysis; manuscript; 
medRxiv preprint doi: https://doi.org/10.1101/2020.12.09.20246520; this version posted December 11, 2020. The copyright holder for this preprint (which was not certified by peer review) is the author/funder, who has granted medRxiv a license to display the preprint in perpetuity.

It is made available under a CC-BY-NC-ND 4.0 International license .

24 LG - study design, manuscript;

25 BJK - study design, data analysis, manuscript

\section{DISCLOSURES}

27 The authors report no relevant disclosures.

\section{DATA AVAILABILITY}

29 Data, analysis scripts, and model code are available at github.com/bjklab.

\section{KEYWORDS}

31 SARS-CoV-2, cycle of threshold, test sensitivity

\section{Acknowledgements:}

33 BJK, MJZ, and EL are supported in part by a CDC Cooperative Agreement FOA\#CK16-004

34 "Epicenters for the Prevention of Healthcare Associated Infections". BJK is supported by the

35 National Institute for Allergy and Infectious Diseases (K23 Al121485 and L30 Al120149). MJZ is

36 supported by the National Institute for Allergy and Infectious Diseases (K23 Al143925). 
medRxiv preprint doi: https://doi.org/10.1101/2020.12.09.20246520; this version posted December 11, 2020. The copyright holder for this preprint (which was not certified by peer review) is the author/funder, who has granted medRxiv a license to display the preprint in perpetuity.

It is made available under a CC-BY-NC-ND 4.0 International license .

\section{$48 \quad$ Abstract}

49 Background: The SARS-CoV-2 reverse-transcription polymerase chain reaction (RT-PCR)

50 cycle of threshold (Ct) has been used to estimate quantitative viral load, with the goal of

51 targeting isolation precautions for individuals with COVID-19 and guiding public health

52 interventions. However, variability in specimen quality can alter the Ct values obtained from

53 SARS-CoV-2 clinical assays. We sought to define how variable nasopharyngeal (NP) swab

54 quality impacts clinical SARS-CoV-2 test sensitivity.

55 Methods: We performed amplification of a human gene target ( $\beta$-actin) in parallel with a clinical

56 RT-PCR targeting the SARS-CoV-2 ORF1ab gene for 1311 NP specimens collected from

57 patients with clinical concern for COVID-19. We evaluated the relationship between NP

58 specimen quality, characterized by high $\mathrm{Ct}$ values for the human gene target $\beta$-actin $\mathrm{Ct}$, and the

59 probability of SARS-CoV-2 detection via logistic regression, as well as the linear relationship

60 between SARS-CoV-2 and $\beta$-actin Ct.

61 Results: Low quality NP swabs are less likely to detect SARS-CoV-2 (odds ratio 0.654, 95\%Cl

620.523 to 0.802$)$. We observed a positive linear relationship between SARS-CoV-2 and $\beta$-actin Ct

63 values (slope $0.169,95 \% \mathrm{Cl} 0.092$ to 0.247 ). COVID-19 disease severity was not associated

64 with $\beta$-actin Ct values.

65 Conclusions: Variability in NP specimen quality accounts for significant differences in the

66 sensitivity of clinical SARS-CoV-2 assays. If unrecognized, low quality NP specimens, which are

67 characterized by a low level of amplifiable human DNA target, may limit the application of

68 SARS-CoV-2 Ct values to direct infection control and public health interventions.

69 
medRxiv preprint doi: https://doi.org/10.1101/2020.12.09.20246520; this version posted December 11, 2020. The copyright holder for this preprint (which was not certified by peer review) is the author/funder, who has granted medRxiv a license to display the preprint in perpetuity.

It is made available under a CC-BY-NC-ND 4.0 International license.

\section{Introduction:}

72 As the COVID-19 pandemic continues to drive morbidity and mortality around the world, interest

73 has grown in using SARS-CoV-2 reverse-transcription polymerase chain reaction (RT-PCR)

74 cycle of threshold (Ct) values as a means of quantifying viral load $(1,2)$. It has been proposed

75 that SARS-CoV-2 Ct values may correspond with viral burden and infectivity, and that SARS-

76 CoV-2 values may be used to predict disease severity and guide isolation precautions for

77 individuals with COVID-19 (3-7). SARS-CoV-2 Ct values have been shown to correspond with

78 community COVID-19 burden, and it has also been proposed that community Ct values may

79 help to guide non-pharmaceutical interventions to control COVID-19 (8).

80 We sought to understand the impact of nasopharyngeal (NP) specimen swab quality on the

81 measurement of SARS-CoV-2 Ct and the sensitivity of virus detection. To collect an NP swab

82 for SARS-CoV-2 testing, healthcare workers are instructed to advance a synthetic fiber swab

83 with plastic or wire shaft through the nostril until contacting the posterior nasopharynx at a depth

84 equal to the distance from the nostril to the opening of the ear, then to rub and roll the swab,

85 leaving the swab in place for several seconds to collect secretions, before rotating the swab

86 further as it is removed from the nostril (9). Variability in practice and patient tolerance of the

87 procedure has been observed, and may impact the sensitivity of SARS-CoV-2 detection, as well

88 as the cycle threshold (Ct) value observed when SARS-CoV-2 is detected (10-12).

89 To measure variability in the quality of NP swab collection, we performed amplification of a

90 human gene target ( $\beta$-actin) in parallel with RT-PCR targeting the SARS-CoV-2 ORF1ab gene.

91 High $\beta$-actin Ct values have been previously validated as a marker of poor NP swab quality (2,

92 13). Below we report the relationship between quality of NP swab collection, sensitivity of

93 SARS-CoV-2 detection, and the range of impact we expect sub-standard NP swab collection

94 may exert on SARS-CoV-2 Ct values. We also examine the possibility of confounding by

95 COVID-19 disease severity. 
medRxiv preprint doi: https://doi.org/10.1101/2020.12.09.20246520; this version posted December 11, 2020. The copyright holder for this preprint (which was not certified by peer review) is the author/funder, who has granted medRxiv a license to display the preprint in perpetuity.

It is made available under a CC-BY-NC-ND 4.0 International license .

97 Materials and Methods:

98 Study Design, Setting, and Population: We performed a retrospective cohort study, capturing

99 consecutive SARS-CoV-2 RT-PCR tests performed at the Clinical Microbiology Laboratory of

100 the Hospital of the University of Pennsylvania between March 26 and July 4, 2020. We included

101 all SARS-CoV-2 RT-PCR results performed on NP specimens via the BD Max SARS-CoV-2

102 assay (Becton Dickinson) for which a positive PCR control analyte (MS2 phage DNA) was

103 detected. A total of 1311 NP specimens were included. All specimens were assayed for $\beta$-actin

104 and MS2 phage DNA in parallel with SARS-CoV-2. A waiver of informed consent was granted

105 by the University of Pennsylvania Institutional Review Board (IRB protocols \#843085 \&

$106 \# 843274)$.

107 Causal Models: We hypothesized that $\beta$-actin and SARS-CoV-2 Ct values are related because

108 poor NP specimen collection technique results in reduced capture of NP epithelial cells and

109 SARS-CoV-2 alike. $\beta$-actin is a commonly used endogenous reference gene, used as an

110 internal control for PCR reactions involving human specimens. This gene has been previously

111 validated as a marker for the presence of nasal epithelial cells, and prior research has

112 supported its use to assess the quality of self-collected midturbinate swabs $(2,13)$. We

113 additionally considered the possibility of confounding by COVID-19 severity of illness. It is

114 possible that those with more severe infection may have greater NP epithelial cell damage,

115 resulting in greater detection of both PCR targets, irrespective of sampling technique.

116 Clinical Data Collection: To evaluate the possibility of confounding by disease severity, we

117 measured two independent markers of respiratory illness: (1) the minimum room-air oxygen

118 saturation recorded within 2 days of SARS-CoV-2 testing, and (2) whether infiltrates were

119 observed chest computerized tomography (CT) imaging performed within 7 days of SARS-CoV- 
medRxiv preprint doi: https://doi.org/10.1101/2020.12.09.20246520; this version posted December 11 , 2020. The copyright holder for this preprint (which was not certified by peer review) is the author/funder, who has granted medRxiv a license to display the preprint in perpetuity.

It is made available under a CC-BY-NC-ND 4.0 International license .

1202 testing. Per Centers for Disease Control and Prevention (CDC) guidelines(14), we considered

121 room-air oxygen saturation < 94\% indicative of severe respiratory illness. Radiology reports for

122 CT imaging that described parenchymal lung disease, including "infiltrates", "pneumonia",

123 "groundglass", or other "opacities", were considered indicative of severe respiratory illness. The

124 presence of lung nodules, lung masses, chronic airway disease including bronchiectasis,

125 emphysematous changes, or pleural effusions in the absence of parenchymal disease as

126 described above, were not considered indicative of severe acute respiratory illness.

127 Specimen Collection, Processing, and RT-PCR Assay: Specimens were collected during

128 routine clinical practice using a nylon flocked mini-tip swab collected in VTM or saline.

129 Healthcare providers obtained samples using CDC guidelines for NP samples collection.

130 Samples were transported to the laboratory at ambient temperature and stored at $4^{\circ} \mathrm{C}$ if not run

131 immediately. Exk TNA2 extraction reagent kits (Becton Dickinson) for the BD MAX open system

132 reagent suite were used for the lab-developed SARS-CoV-2 assay based on a previously

133 described assay $(15,16)$. The BD MAX system was set to run type 1 workflow. PCR conditions

134 consisted of a reverse transcriptase step $\left(600\right.$ s at $58^{\circ} \mathrm{C}, 1$ cycle), denaturation step (60s at

$13598^{\circ} \mathrm{C}, 1$ cycle) and extension steps $\left(10 \mathrm{~s}\right.$ at $98^{\circ} \mathrm{C}$ followed by 40 s at $63^{\circ} \mathrm{C}, 40$ cycles). Two

136 different sets of primer/probe master mix were prepared and $12.5 \mu$ was aliquoted into BD MAX

$1370.3 \mathrm{~mL}$ snap-in conical tubes for storage at $-70^{\circ} \mathrm{C}$ prior to use. The LUNA Universal Probe One-

138 Step RT-qPCR kit (New England Biolabs) was used to prepare the master mix according to

139 manufacturer guidelines with modified primer and probe concentrations. Master mix 1 was

140 composed of the SARS-CoV-2 orf1ab target $(0.6 \mu \mathrm{M}$ primers and $0.2 \mu \mathrm{M}$ probe, sequences:

141 unpublished data), and the internal processing control MS2 bacteriophage $(0.1 \mu \mathrm{M}$ primers and

142 probe, sequences) (17). Master mix 2 contained the $\beta$-actin primers $(0.6 \mu \mathrm{M})$ and probe $(0.2$

$143 \mu \mathrm{M})(18)$. Samples were prepared by adding $200 \mu \mathrm{l}$ of NP specimen and $20 \mu \mathrm{l}$ of specimen

144 processing control (5x106 pfu/mL MS2 Phage; Zeptometrix) to an Exk TNA2 sample buffer 
medRxiv preprint doi: https://doi.org/10.1101/2020.12.09.20246520; this version posted December 11, 2020. The copyright holder for this preprint (which was not certified by peer review) is the author/funder, who has granted medRxiv a license to display the preprint in perpetuity.

It is made available under a CC-BY-NC-ND 4.0 International license .

145 tube. Sample buffer tubes containing patient specimens were loaded onto the BD MAX System

146 racks along with the Exk TNA2 test strips. Master mix 1, neutralization buffer (25 $\mu$ I NucliSENS

147 easyMAG Extraction Buffer 3, Biomerieux) and master mix 2 were snapped in to open positions

1482 to 4 , respectively, on the test strip prior to loading the rack onto the BD MAX system. All NP

149 samples for which the specimen processing control target (MS2) was detected were included in

150 the study $(n=1311)$. Ct values for all three targets ( $\beta$-actin, MS2 and SARS-CoV-2) were

151 recorded.

152 Definition of Exposures and Outcomes: The primary exposure of interest was the $\beta$-actin Ct

153 value, a surrogate for the quality of NP swab collection. The primary outcome of interest was

154 SARS-CoV-2 Ct value.

155 Statistical Methods: Data were organized using R statistical software version 3.6.1 (19), and

156 plots generated using the "ggplot2" package (20). Where $\beta$-actin and SARS-CoV-2 were not

157 detected, Ct values were imputed as 40 cycles. We examined (1) the linear relationship

158 between $\beta$-actin and SARS-CoV-2 Ct values, as well as (2) the impact of $\beta$-actin Ct on SARS-

159 CoV-2 detection using Bayesian linear and generalized-linear mixed effects models, which were

160 fit using Stan Hamiltonian Monte Carlo (HMC) version 2.21, via the "brms" package with default

161 weakly-informative priors $(21,22)$. Prior predictive modeling was performed, and models were fit

162 with 4 chains of 1000 iterations, confirmed with HMC diagnostics (no divergent iterations, Rhat

163 statistic $<1.1$ for all parameters, and E-BFMI > 0.2) (23-25). We examined parameter

164 distributions at 50\%, 80\%, and 95\% posterior credible intervals to understand the relationship

165 between exposure and outcome variables.

166 Power and Sample Size: We estimated the necessary cohort size based on the anticipated

167 effect of poor NP swab quantity (26). We anticipated that approximately 800 subjects would

168 detect a $10 \%$ reduction in sensitivity of SARS-CoV-2 detection related to a $\beta$-actin Ct increase of

16910 , with credible intervals precision ensuring type S error $<5 \%(27,28)$. We targeted enrollment 
medRxiv preprint doi: https://doi.org/10.1101/2020.12.09.20246520; this version posted December 11, 2020. The copyright holder for this preprint (which was not certified by peer review) is the author/funder, who has granted medRxiv a license to display the preprint in perpetuity.

It is made available under a CC-BY-NC-ND 4.0 International license .

170 of $10 \%$ more subjects to allow for a margin of error in that estimate, and we exceeded our

171 enrollment target.

172 Availability of Data: Data, analysis scripts, and model code are available at github.com/bjklab.

174 Results:

175 SARS-CoV-2 Detection and Cycle of Threshold Range: Of 1311 tested specimens, 138 were

176 found to have detectable SARS-CoV-2 within 40 cycles of PCR. Among these specimens,

177 median SARS-CoV-2 Ct was 28.15 (IQR 20.5 to 32.98). No secular trend was observed

178 between calendar time from local onset of COVID-19 cases and SARS-CoV-2 Ct values during

179 the study period (Pearson correlation 0.18). Figure 1 depicts the distribution of SARS-CoV-2 Ct

180 values.

181 Relationship between $\beta$-Actin and SARS-CoV-2 Cycle of Threshold: We evaluated the

182 relationship between NP specimen quality, meaured by $\beta$-actin Ct value, and SARS-CoV-2 test

183 sensitivity with logistic regression, and we found that increasing $\beta$-actin is significantly

184 associated with reduced detection of SARS-CoV-2 (odds ratio $0.654,95 \% \mathrm{Cl} 0.523$ to 0.802 ).

185 Figure 2 depicts the relationship between $\beta$-actin and SARS-CoV-2 detection probability. We

186 further evaluated the linear relationship between $\beta$-actin and SARS-CoV-2 Ct values with linear

187 regression, and we found that SARS-CoV-2 Ct increases significantly with $\beta$-actin Ct (slope

$188 \quad 0.169,95 \% \mathrm{Cl} 0.092$ to 0.247$)$. A linear model restricted to include only the 134 specimens

189 within which both SARS-CoV-2 and $\beta$-actin were detectable (i.e., Ct $<40$ ) also found that

190 SARS-CoV-2 Ct increased with $\beta$-actin, but this relationship did not have high posterior certainty

191 (slope $0.254,95 \% \mathrm{Cl}-0.23$ to 0.73 ), and linear model fit was poor.

192 Impact of Poor NP Specimen Quality on SARS-CoV-2 Detection Sensitivity: To understand

193 the potential impact of poor NP specimen quality, we evaluated the change in probability of 
medRxiv preprint doi: https://doi.org/10.1101/2020.12.09.20246520; this version posted December 11, 2020. The copyright holder for this preprint (which was not certified by peer review) is the author/funder, who has granted medRxiv a license to display the preprint in perpetuity.

It is made available under a CC-BY-NC-ND 4.0 International license .

194 SARS-CoV-2 detection as $\beta$-actin Ct increases. We found that a 4-Ct increase in $\beta$-actin, from

195 Ct of 28 to $\mathrm{Ct}$ of 32 (roughly from the first quartile of observed $\beta$-actin Ct values to the third

196 quartile) results in a 5.4\% $(95 \% \mathrm{Cl} 2.7 \%$ to $8.2 \%)$ decreased probability of SARS-CoV-2

197 detection.

198 Impact of Disease Severity on Relationship Between $\beta$-Actin and SARS-CoV-2 Cycle of

199 Threshold: Considering the possibility that the observed association between SARS-CoV-2 and

$200 \beta$-actin Ct values is confounded by respiratory illness severity, we evaluated the relationship

201 between $\beta$-actin Ct and independent markers of respiratory illness. Oxygen saturation data were

202 available for 428 (32.6\%) subjects; chest CT imaging was available for 111 (8.5\%) subjects.

203 Linear regression relating $\beta$-actin Ct values to oxygen saturation revealed no significant

204 association, and the point estimate of association ran counter to concern for confounding by

205 disease severity. Lower oxygen saturation was in fact associated with higher $\beta$-actin Ct values

206 (less $\beta$-actin amplicon), with linear regression slope -0.04 (95\% Cl -0.273 to 0.182$)$. Similarly, we

207 found that the presence of parenchymal lung disease on chest CT radiography reports had no

208 significant association with $\beta$-actin Ct values, and that the point estimate of association actually

209 suggests lung parenchymal infiltrates are associated with higher $\beta$-actin Ct values (less $\beta$-actin

210 Ct amplicon) with linear regression slope $0.428(95 \% \mathrm{Cl}-0.655$ to 1.61$)$. These analyses of

211 independent markers of severe respiratory disease suggest that it is NP specimen quality, not

212 disease severity, that drives the association between SARS-CoV-2 and $\beta$-actin Ct values.

\section{Discussion:}

215 In this study, we found that higher $\beta$-actin Ct values, which have been previously validated as a

216 marker of low NP swab quality $(2,13)$, were associated with reduced probability of SARS-CoV-2

217 detection (odds ratio $0.654,95 \% \mathrm{Cl} 0.523$ to 0.802 ) and with higher SARS-CoV-2 Ct values 
medRxiv preprint doi: https://doi.org/10.1101/2020.12.09.20246520; this version posted December 11, 2020. The copyright holder for this preprint (which was not certified by peer review) is the author/funder, who has granted medRxiv a license to display the preprint in perpetuity.

It is made available under a CC-BY-NC-ND 4.0 International license .

218 (linear regression slope $0.169,95 \% \mathrm{Cl} 0.092$ to 0.247 ). In our cohort, we observed $10.5 \%$ of

219 tested NP specimens had detectable SARS-CoV-2. Based on the observed impact of NP

220 specimen quality, we estimate that the reduction of quality NP specimen collection that results in

$221 \quad \beta$-actin Ct increasing from 28 to 32 (roughly $25 \%$ to $75 \%$ percentile) decreases the absolute

222 probability of SARS-CoV-2 detection by $5.4 \%(95 \% \mathrm{Cl} 2.7 \%$ to $8.2 \%)$. This finding has several

223 important implications. First, the correlation between $\beta$-actin Ct and SARS-CoV-2 suggests that

224 quantitative interpretation of SARS-CoV-2 human specimens may be enhanced by adjusting for

225 the $\beta$-actin Ct. Second, the data support the concern that poor specimen collection may

226 contribute to false-negative results. The concern of false-negative NP SARS-CoV-2 testing has

227 led to the recommendation to retest patients with moderate to high clinical suspicion of COVID-

$22819(29,30)$. Reporting the $\beta$-actin Ct, or a $\beta$-actin-adjusted SARS-CoV-2 Ct may allow clinicians

229 to better interpret specimen quality when considering retesting.

230 We considered the possibility that the observed relationship between SARS-CoV-2 and $\beta$-actin

231 Ct values might be confounded by respiratory disease severity, but we found no significant

232 association between independent markers of severe respiratory disease and lower $\beta$-actin $\mathrm{Ct}$

233 values. However, several limitations of our analysis must be acknowledged. Oxygen saturation

234 data and chest CT radiography reports were only available for a small percentage (32.6\% and

$2358.5 \%$, respectively) of our subjects. Subject demographics and medical comorbidities could not

236 be ascertained for subjects, so unmeasured confounders may contribute to the observed

237 association.

238 Nevertheless, we believe that the observed association between NP specimen quality and

239 SARS-CoV-2 RT-PCR sensitivity is an important finding. From 1311 NP specimens submitted

240 for SARS-CoV-2 testing, we have quantified the variation in specimen quality measured by $\beta$ -

241 actin Ct value, and we have defined the impact of the observed variation on test sensitivity and

242 SARS-CoV-2 Ct values. 
medRxiv preprint doi: https://doi.org/10.1101/2020.12.09.20246520; this version posted December 11, 2020. The copyright holder for this preprint (which was not certified by peer review) is the author/funder, who has granted medRxiv a license to display the preprint in perpetuity.

It is made available under a CC-BY-NC-ND 4.0 International license .

243 SARS-CoV-2 Ct values have shown promise as a means to roughly quantify viral burden and so

244 to guide infection control and public health interventions (1, 2, 4-8). However, variability in NP

245 specimen collection may exert large effects on observed SARS-CoV-2 Ct values, limiting these

246 useful applications. As testing efforts expand, infrastructure to ensure quality sample collection

247 must expand as well (9). Concurrent measurement of a $\beta$-actin human gene target may provide

248 a means to recognize and adjust for variability in NP specimen quality.

256 Figures:

257 Figure 1: Distribution and relationships of Ct values for SARS-CoV-2, $\beta$-actin, and MS2

258 DNA positive control. A matrix plot depicting the observed cycle of threshold values for SARS-

259 CoV-2 RT-PCR, with MS2 DNA positive control and $\beta$-actin specimen quality control over 1311

260 consecutive clinical assays run between March 26 and July 4, 2020. Panels on the diagonal

261 present the distribution of each target's Ct values. Panels off the diagonal present the

262 relationship between Ct values for each pair of targets. Ct for specimens without detectable

263 SARS-CoV-2 or $\beta$-actin were imputed at 40 cycles. 
medRxiv preprint doi: https://doi.org/10.1101/2020.12.09.20246520; this version posted December 11, 2020. The copyright holder for this preprint (which was not certified by peer review) is the author/funder, who has granted medRxiv a license to display the preprint in perpetuity.

It is made available under a CC-BY-NC-ND 4.0 International license .

265 Figure 2: Relationship between $\beta$-actin and SARS-CoV-2 detection probability. Binomial

266 logistic regression relating SARS-CoV-2 detection to $\beta$-actin Ct value reveals a negative

267 association, with high $\beta$-actin Ct (i.e., low quality) NP specimens less likely to detect SARS-

268 CoV-2. The absolute probabiity of SARS-CoV-2 detection is presented in relation to the

269 observed range of $\beta$-actin Ct values.

270

271

272

273

274

275

276 REFERENCES

277 1. He X, Lau EHY, Wu P, Deng X, Wang J, Hao X, Lau YC, Wong JY, Guan Y, Tan X, Mo X,

278 Chen Y, Liao B, Chen W, Hu F, Zhang Q, Zhong M, Wu Y, Zhao L, Zhang F, Cowling BJ, Li F,

279 Leung GM. 2020. Temporal dynamics in viral shedding and transmissibility of COVID-19. Nature

280 medicine 26:672-675.

281 2. Singanayagam A, Patel M, Charlett A, Lopez Bernal J, Saliba V, Ellis J, Ladhani S, Zambon

282 M, Gopal R. 2020. Duration of infectiousness and correlation with RT-PCR cycle threshold

283 values in cases of COVID-19, england, january to may 2020. Euro surveillance: bulletin

284 Europeen sur les maladies transmissibles = European communicable disease bulletin 25. 
medRxiv preprint doi: https://doi.org/10.1101/2020.12.09.20246520; this version posted December 11, 2020. The copyright holder for this preprint (which was not certified by peer review) is the author/funder, who has granted medRxiv a license to display the preprint in perpetuity.

It is made available under a CC-BY-NC-ND 4.0 International license .

285

286

287

288

289

290

291

292

293

294

295

296

297

298

299

300

301

302

303

304

305

306

307

308

3. Westblade LF, Brar G, Pinheiro LC, Paidoussis D, Rajan M, Martin P, Goyal P, Sepulveda JL, Zhang L, George G, Liu D, Whittier S, Plate M, Small CB, Rand JH, Cushing MM, Walsh TJ, Cooke J, Safford MM, Loda M, Satlin MJ. 2020. SARS-CoV-2 viral load predicts mortality in patients with and without cancer who are hospitalized with COVID-19. Cancer cell 38:661671.e2.

4. Rhee C, Kanjilal S, Baker M, Klompas M. 2020. Duration of severe acute respiratory syndrome coronavirus 2 (SARS-CoV-2) infectivity: When is it safe to discontinue isolation? Clinical infectious diseases: an official publication of the Infectious Diseases Society of America https://doi.org/10.1093/cid/ciaa1249.

5. Tom MR, Mina MJ. 2020. To interpret the SARS-CoV-2 test, consider the cycle threshold value. Clinical infectious diseases: an official publication of the Infectious Diseases Society of America 71:2252-2254.

6. Alteri C, Cento V, Vecchi M, Colagrossi L, Fanti D, Vismara C, Puoti M, Perno CF, SCOVA Study Group. 2020. Nasopharyngeal SARS-CoV-2 load at hospital admission as predictor of mortality. Clinical infectious diseases: an official publication of the Infectious Diseases Society of America https://doi.org/10.1093/cid/ciaa956.

7. Binnicker MJ. 2020. Challenges and controversies to testing for COVID-19. Journal of clinical microbiology 58.

8. Hay JA, Kennedy-Shaffer L, Kanjilal S, Lipsitch M, Mina MJ. 2020. Estimating epidemiologic dynamics from single cross-sectional viral load distributions. medrxiv;2020.10.08.20204222v1. Epidemiology. medRxiv.

9. Procop GW, Shrestha NK, Vogel S, Van Sickle K, Harrington S, Rhoads DD, Rubin BP, Terpeluk P. 2020. A direct comparison of enhanced saliva to nasopharyngeal swab for the detection of SARS-CoV-2 in symptomatic patients. Journal of clinical microbiology 58. 
309 10. Sethuraman N, Jeremiah SS, Ryo A. 2020. Interpreting diagnostic tests for SARS-CoV-2.

310 JAMA: the journal of the American Medical Association 323:2249-2251.

311 11. Fang Y, Zhang H, Xie J, Lin M, Ying L, Pang P, Ji W. 2020. Sensitivity of chest CT for

312 COVID-19: Comparison to RT-PCR. Radiology 296:E115-E117.

313 12. Higgins TS, Wu AW, Ting JY. 2020. SARS-CoV-2 nasopharyngeal swab Testing-False-

314 Negative results from a pervasive anatomical misconception. JAMA otolaryngology- head \&

315 neck surgery https://doi.org/10.1001/jamaoto.2020.2946.

316 13. Smieja M, Castriciano S, Carruthers S, So G, Chong S, Luinstra K, Mahony JB, Petrich A,

317 Chernesky M, Savarese M, Triva D. 2010. Development and evaluation of a flocked nasal

318 midturbinate swab for self-collection in respiratory virus infection diagnostic testing. Journal of

319 clinical microbiology 48:3340-3342.

320 14. CDC. 2020. Discontinuation of Transmission-Based precautions and disposition of patients

321 with COVID-19 in healthcare settings (interim guidance). https://www.cdc.gov/coronavirus/2019-

322 ncov/hcp/disposition-hospitalized-patients.html.

323 15. LeBlanc JJ, Gubbay JB, Li Y, Needle R, Arneson SR, Marcino D, Charest H, Desnoyers G,

324 Dust K, Fattouh R, Garceau R, German G, Hatchette TF, Kozak RA, Krajden M, Kuschak T,

325 Lang ALS, Levett P, Mazzulli T, McDonald R, Mubareka S, Prystajecky N, Rutherford C, Smieja

326 M, Yu Y, Zahariadis G, Zelyas N, Bastien N, COVID-19 Pandemic Diagnostics Investigation

327 Team of the Canadian Public Health Laboratory Network (CPHLN) Respiratory Virus Working

328 Group. 2020. Real-time PCR-based SARS-CoV-2 detection in canadian laboratories. Journal of

329 clinical virology: the official publication of the Pan American Society for Clinical Virology

$330128: 104433$. 
medRxiv preprint doi: https://doi.org/10.1101/2020.12.09.20246520; this version posted December 11, 2020. The copyright holder for this preprint (which was not certified by peer review) is the author/funder, who has granted medRxiv a license to display the preprint in perpetuity.

It is made available under a CC-BY-NC-ND 4.0 International license .

331 16. Vermeiren C, Marchand-Senécal X, Sheldrake E, Bulir D, Smieja M, Chong S, Forbes JD,

332 Katz K. 2020. Comparison of copan ESwab and FLOQSwab for COVID-19 diagnosis: Working

333 around a supply shortage. Journal of clinical microbiology 58.

334 17. Rolfe KJ, Parmar S, Mururi D, Wreghitt TG, Jalal H, Zhang H, Curran MD. 2007. An

335 internally controlled, one-step, real-time RT-PCR assay for norovirus detection and

336 genogrouping. Journal of clinical virology: the official publication of the Pan American Society for

337 Clinical Virology 39:318-321.

338 18. Bas A, Forsberg G, Hammarström S, Hammarström M-L. 2004. Utility of the housekeeping

339 genes 18S rRNA, beta-actin and glyceraldehyde-3-phosphate-dehydrogenase for normalization

340 in real-time quantitative reverse transcriptase-polymerase chain reaction analysis of gene

341 expression in human T lymphocytes. Scandinavian journal of immunology 59:566-573.

342 19. R Core Team. 2018. R: A language and environment for statistical computing. R Foundation

343 for Statistical Computing, Vienna, Austria.

344 20. Wickham H. 2016. Ggplot2: Elegant graphics for data analysis1st ed. 2009. Corr. 3rd

345 printing 2010 edition. Springer International Publishing.

346 21. Carpenter B, Gelman A, Hoffman M, Lee D, Goodrich B, Betancourt M, Brubaker M, Guo J,

347 Li P, Riddell A. 2017. Stan: A probabilistic programming language. Journal of statistical software $34876: 1-32$.

349 22. Bürkner P-C. 2017. Brms: An R package for bayesian multilevel models using stan. Journal 350 of Statistical Software, Articles 80:1-28.

351 23. McElreath R. 2016. Statistical rethinking: A bayesian course with examples in R and stan1 352 edition. CRC Press/Taylor \& Francis Group. 
medRxiv preprint doi: https://doi.org/10.1101/2020.12.09.20246520; this version posted December 11, 2020. The copyright holder for this preprint (which was not certified by peer review) is the author/funder, who has granted medRxiv a license to display the preprint in perpetuity.

It is made available under a CC-BY-NC-ND 4.0 International license .

353 24. Gabry J, Simpson D, Vehtari A, Betancourt M, Gelman A. 2019. Visualization in bayesian

354 workflow. Journal of the Royal Statistical Society Series A, 182:389-402.

355 25. Gelman A, Vehtari A, Simpson D, Margossian CC, Carpenter B, Yao Y, Kennedy L, Gabry

356 J, Bürkner P-C, Modrák M. 2020. Bayesian workflow.

357 26. Rothman KJ, Greenland S. 2018. Planning study size based on precision rather than power.

358 Epidemiology 29:599-603.

359 27. Gelman A, Tuerlinckx F. 2000. Type S error rates for classical and bayesian single and

360 multiple comparison procedures. Computational statistics 15:373-390.

361 28. Gelman A, Carlin J. 2014. Beyond power calculations: Assessing type S (sign) and type M

362 (magnitude) errors. Perspectives on psychological science: a journal of the Association for

363 Psychological Science 9:641-651.

364 29. Gniazdowski V, Morris CP, Wohl S, Mehoke T, Ramakrishnan S, Thielen P, Powell H, Smith

365 B, Armstrong DT, Herrera M, Reifsnyder C, Sevdali M, Carroll KC, Pekosz A, Mostafa HH.

366 2020. Repeat COVID-19 molecular testing: Correlation of SARS-CoV-2 culture with molecular

367 assays and cycle thresholds. Clinical infectious diseases: an official publication of the Infectious

368 Diseases Society of America https://doi.org/10.1093/cid/ciaa1616.

369 30. Hanson KE, Caliendo AM, Arias CA, Englund JA, Lee MJ, Loeb M, Patel R, El Alayli A,

370 Kalot‘ MA, Falck-Ytter Y, Lavergne V, Morgan RL, Hassan Murad M, Sultan S, Bhimraj A,

371 Mustafa RA. 2020. Infectious diseases society of america guidelines on the diagnosis of

372 COVID-19.

373

374 
MS2 Ct
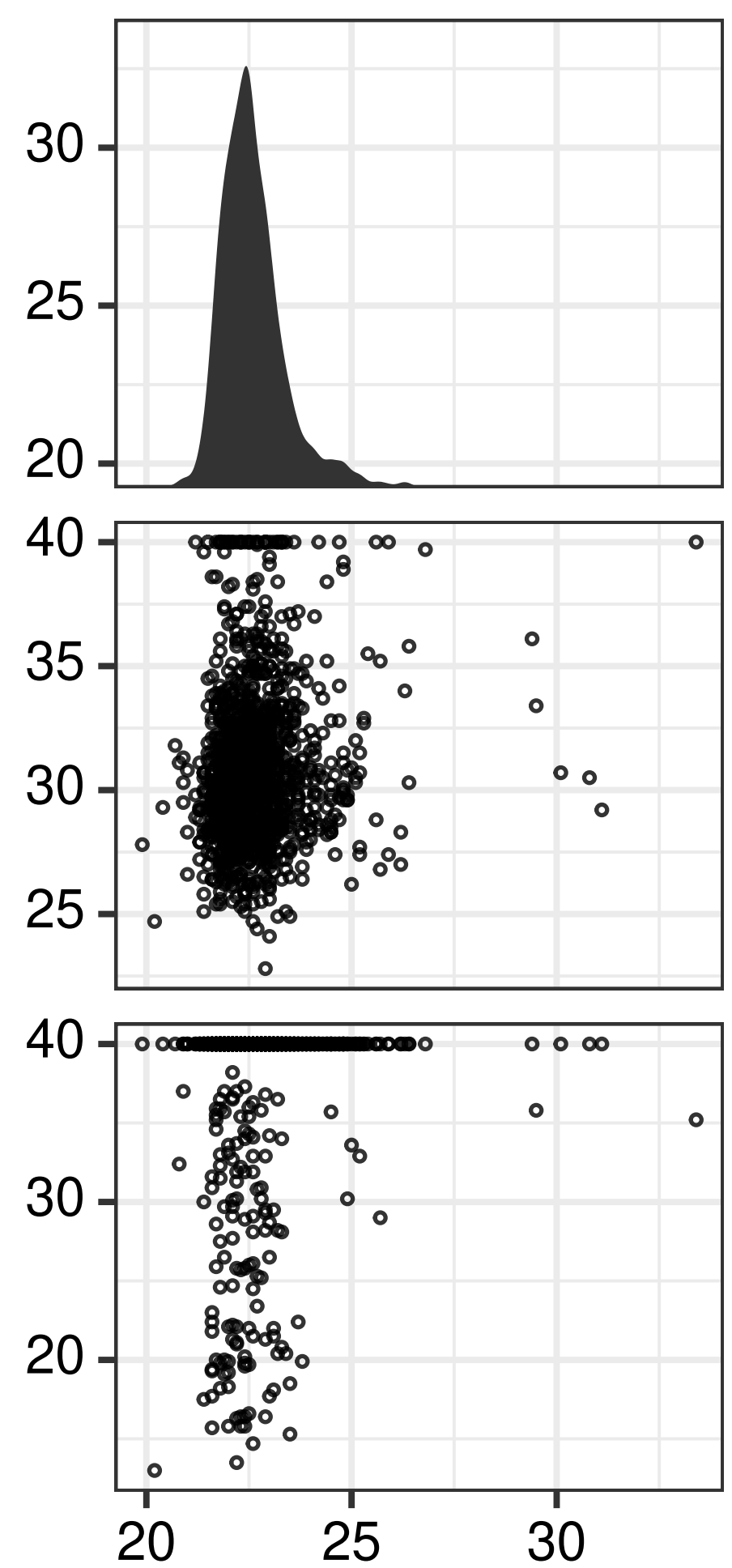

..-actin $\mathrm{Ct}$
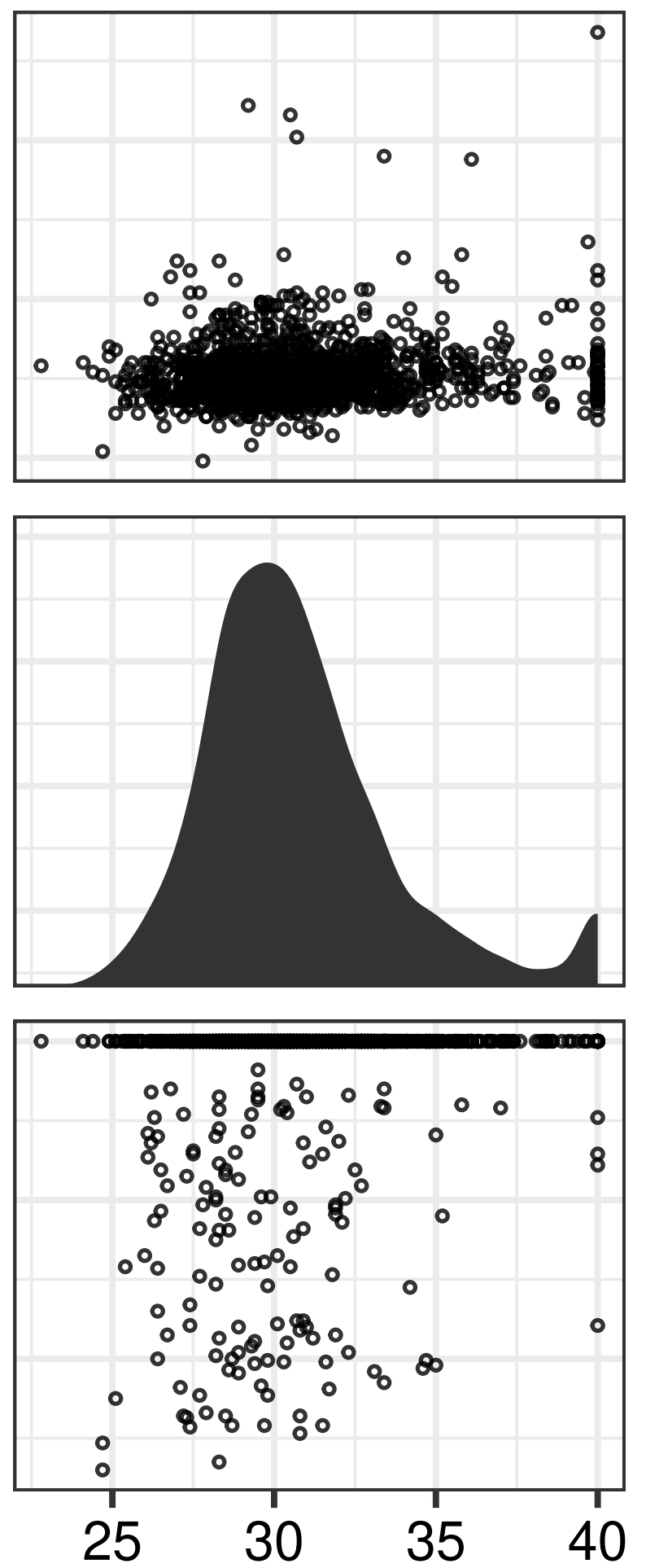

SARS-CoV-2 Ct
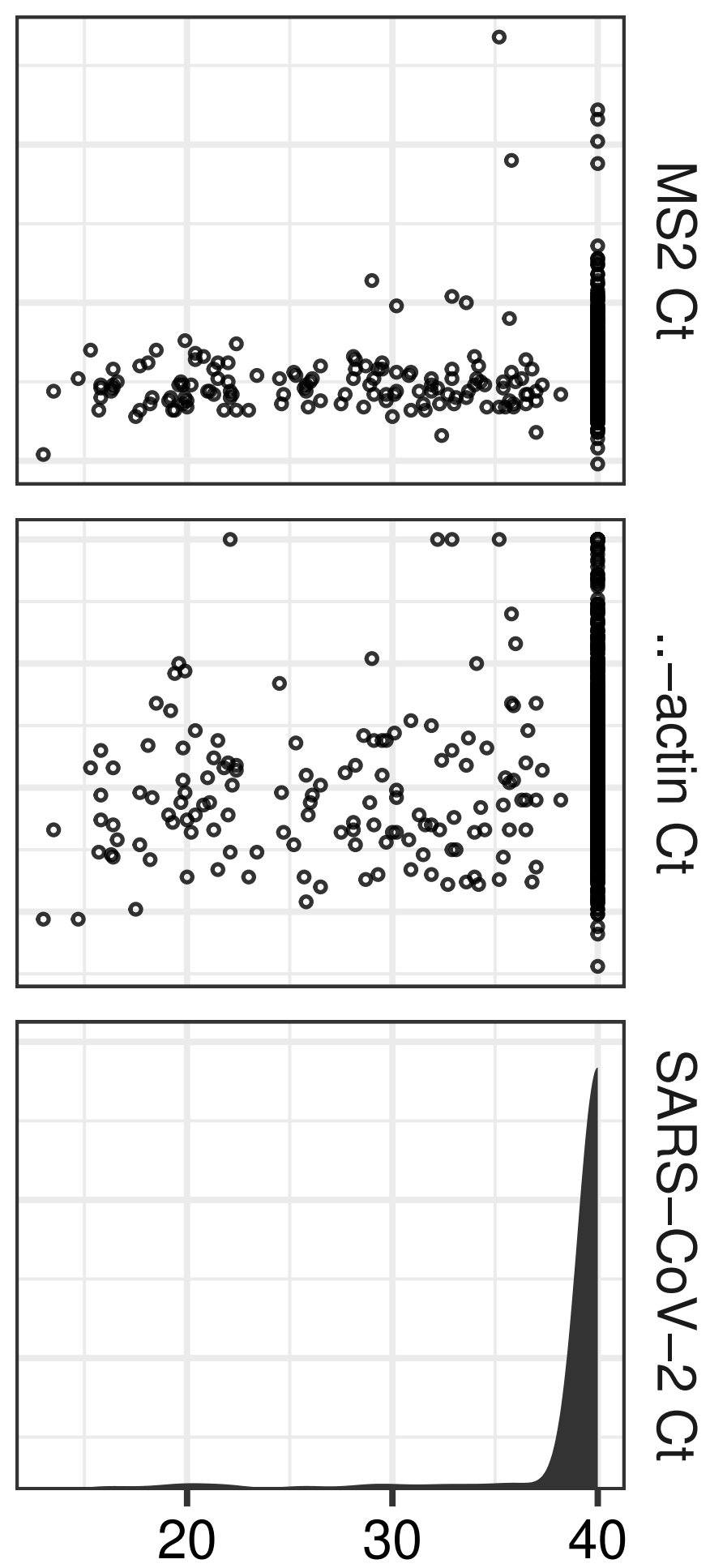
